\title{
Raising Atlantis: the Later Heidegger and Contemporary Philosophy
}

(c) David Kolb, 1995

What does Heidegger have to contribute to contemporary philosophy? In this essay I will mean by "contemporary philosophy" mostly Anglo-American-European "analytic" philosophy. That is itself

hardly a united movement, but much of it shares certain basic methods and goals for the construction and defense of philosophical positions.

Of course, Heidegger has had great influence on the varied movements that go under the name of "continental" philosophy, but there his influence is an ongoing topic of conversation. My question is: does Heidegger have contributions to make in circles where he is not a standard topic?

In his later years, Heidegger intended no contribution to contemporary philosophy except to point towards its end. ("End" here can mean finish, as in the end of a race, but also limit, as in the end of a field or property.) Earlier Heidegger had indeed tried to contribute to the debates swirling about in his contemporary philosophy (debates among the schools of Neo-Kantianism, several kinds of positivism, Husserl's phenomenology, and various renewed metaphysics such as that of Nikolai Hartmann). His contributions consisted of phenomenological analyses and historical discussions that led to radical reposings of questions; he attempted to uncover deeply held presuppositions and to redefine terms and programs. In his later work he seems to be saying that philosophy as we know has come to a kind of end (completion, limit) and that real thinking has to do something more.

Fairly direct connections can be drawn between Heidegger's earlier work and many of our contemporary debates. However, I want to experiment with the idea that the most challenging appropriation of Heidegger into contemporary philosophy would be from his later writings: we should not reduce the later Heidegger to any familiar (or even to a new) position within the standard debates. Heidegger wants us to get beyond locating and defending positions. Yet even as he tries to move beyond it Heidegger may make contributions to the standard enterprise.

Heidegger says that philosophy today has become the "scientific attitude of socially active humanity" (EPH 376). ${ }^{1}$ It works out the ontologies of the various regions of entities, analyzing their

$1 \quad$ References to Heidegger's works will be given in the text according to the following abbreviations:

EPH: “The End of Philosophy and the Task of Thinking," translated by Joan Stambaugh, reprinted in Martin Heidegger: Basic Writings, edited by David Krell, (New York: Harper and Row, 1977).

SZ: Sein und Zeit (Tübingen: Niemeyer, 1963), translated as Being and Time (New York: Harper and Row, 1962).

US: Unterwegs zur Sprache (Pfullingen: Neske, 1975). All but one of the essays in the German volume are translated in WL.

WL: On the Way to Language, translated by Peter Hertz and Joan Stambaugh (New York: Harper and Row, 1971).

ZS: "Time and Being," translated by Joan Stambaugh, in On Time and Being (New York: Harper 
structural categories and showing them as grounded in various ways. Staking out and defending positions on that ground is how philosophy pursues its task. ${ }^{2}$

Heidegger wants to undermine such philosophizing, or, better, he wants to let it be but to show that its task responds to a call that it cannot formulate in its own terms. Heidegger questions the independence of philosophy. He wants to know what opens the space for its maneuvers of defense and

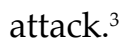

Heidegger usually describes his own thinking in a traditional enough way, as the uncovering of deeply seated presuppositions and the asking of ever more radical questions. However, for the later Heidegger the truest thinking is not questioning but listening.

In his essay "The Essence of Language" he says that every question "already holds itself within the address of that which will stand in question." He says that throughout its history philosophy has sought the grounds for the existence and the nature of the beings it inquires about. Such inquiry seeks grounds, because the meaning of the being (Wesen) of the things inquired about has from the beginning of the West been characterized as grounded presence. Just when thought is at its the most radical it is responding to and within that meaning of being. So, "the proper gesture of thinking cannot be questioning but the hearing of the address of that by which all questioning first asks (anfragt), in so far as it asks after being (dem Wesen nachfragt)." Again, he says that the most proper gesture of thinking is "the hearing of the address of that which is to come into the question." (US 175-6/WL 71-2). Heidegger's phrase, was in die Frage kommen soll could be "what is to be put in question" but it can also be "what is to

and Row, 1972), 1-24.

2 In the modern world this philosophical aim is being accomplished through a thoroughgoing reduction away from the hierarchies of being and privileged "first beings" of traditional philosophy. The so-called anti-metaphysical strain of positivism and of analytic philosophy as Heidegger knew it stands for him as the culmination of the metaphysical drive to make all beings totally present and accountable. This Platonic enterprise is realized in the technological leveling all beings into total availability for handling and information. That, for Heidegger, is what current philosophy has become; he wants to challenge such a task for thinking but not exactly by denying it.

3 It may sound as if Heidegger was attempting to do meta-philosophy (or perhaps meta-metaphilosophy). In a way this is true, but Heidegger is trying to do something other than repeating foundational questions at a meta-level. When he uses the foundational language of deeper movements and further seeings, he tries to twist these gestures so that they are not the same moves repeated. What makes Heidegger's meta-philosophy different from others is that it not supposed to attain an over-view. Heidegger denies that there is a meta-place from which one can have the kind of total vision philosophy urges as its ideal. Metaphysics tries to provide overviews of the world as revealed in a given epoch, and speaks the meaning of being for its time. What it cannot do is close in on the provenance of the meaning of being. Of that "process" there is no overview. Many people take this to be a kind of historicism. Heidegger's talk about "the history of being" reinforces this impression. Heidegger claims that such talk was always a way of getting at the permanent finitude and receptivity of thought. 
come [to us] in the question."

I want to talk about what contributions might be found in that idea of listening to what addresses us.

Philosophers know how to analyze the argument structure of a text or a position and study its context and rhetorical situation. We can locate a text on our maps; we can see whether it belongs to one of the recognized positions, or whether it suggests a new position. We occasionally find deep presuppositions shared even among seeming adversaries. When those presuppositions are challenged, new areas of thought open up. All this is familiar but it is not what Heidegger has in mind. He is talking about more than being attentive to deep presuppositions.

There is more to thinking, according to Heidegger, than attacking and defending positions. Still, we can ask where Heidegger would locate himself if he were forced to rely only on the contemporary map of philosophical positions.

In epistemology and the theory of meaning, he would be opposed to any reliance on direct acquaintance with items that presented themselves without reference to context or ongoing activity. So he would be opposed to epistemologies that favor basic propositions reporting foundational experiences. In the philosophy of language he would be with those who deny that language can be completely formalized. He would support something like a set of transcendental conditions that make language possible. His theory of propositional truth would use the word "correspondence" but be deflationary in

4 My address translates Heidegger's Zusage, which can mean assistance, consolation, exhortation, a speaking to, promise, grant, or acquiescence, abandonment to, consent. The entire passage reads as follows: Anfrage und Nachfrage brauchen hier und überall im voraus den Zuspruch dessen, was sie fragend angehen, dem sie fragend nachgehen. Jeder Ansatz jeder Frage hält sich schon innerhalb der Zusage dessen auf, was in die Frage gestellt wird. Was erfahren wir, wenn wir dies genügend bedenken? Dass das Fragen nicht die eigentliche Gebärde des Denkens ist, sondern--das Hören der Zusage dessen, was in die Frage kommen soll. Nun gilt jedoch von altersher in der Geschichte unseres Denkens das Fragen als der massgebende Zug des Denkens, und dies nicht von ungefähr. Ein Denken ist um so denkender, je radikaler es sich gebärdet, je mehr es an die radix, and die Wurzel alles dessen geht, was ist. Immer bleibt das Fragen des Denkens das Suchen nach den ersten und letzten Gründen. Weshalb? Weil dies, dass etwas ist und was es ist, weil das Wesende des Wesens von altersher sich als der Grund bestimmt hat. Insofern alles Wesen den Charakter des Grundes hat, ist das Suchen nach dem Wesen der Ergründen und Begründen des Grundes. ... die eigentlich Gebärde des Denkens nicht das Fragen sein kann, sondern das Hören der Zusage dessen sein muss, wobei alles Fragen dann erst anfragt, indem es dem Wesen nachfragt. (US 175-6/ WL 71-2)

After I had been thinking about this passage, I discovered that Derrida had written an enlightening long footnote concerning it in De l'Esprit (Paris: Gallilée, 1987, 147n1). Oddly, just as I realized the relevance of the Derrida passage late in the game, so Derrida was put on to the passage by a colleague after the main text of De l'Esprit was written. This happened, I think, because the passage goes against Heidegger's standard rhetoric about thought's task being that of ever deeper questioning, so the passage tends to recede from view. In his discussion, Derrida shows how the passage invites a retrospective reinterpretation of Heidegger's whole thought, but also why this temptation is inappropriate. 
intent. He would defend ordinary language against reduction. He would not however say that scientific or other theoretical language was purely instrumental; it too is a way of revealing the world. Since Heidegger is some kind of holist, he would thus be in favor of multiple languages for approaching the world.

In ontology, he would oppose ontological reductions, and insist that events and beings can be multiply described. In the philosophy of mind Heidegger would be against the reduction of the intentional to physical descriptions. Among intentionalists, he would oppose any attempt to describe mental life as a series of self-sufficient mental events. ${ }^{5}$

Heidegger opposes Cartesian dualism and its successors but he would be unhappy with the current internalism/externalism debate, because the debate is about affirming or denying an inner experience that is described in terms of objects present to a subject. Heidegger appeals to our experience, but not as an appeal to objects presented to the observing inner eye. He is against the Cartesian inner theater with its ego-spectator. Does this mean that he is an externalist? Does he then adopt the consistent third-person point of view (with its consequent need for radical interpretation)?

Describing his own early work, Heidegger said that he was not talking about a division of inner and outer, which always means a reference back from objects to a subject (Rückbeziehung des Objektiven auf das Subjekt (DL 129f/US )). He said that from the beginning he was out to question the legislative role (massgebenden Rolle) of notions such as "expression, experience, and consciousness" (Ausdruck, Erlebnis, Bewusstsein (DL 130/US )). Nonetheless he does not adopt the third-person perspective that renders intentional experience in terms of imputed beliefs plus perhaps the occurrence of qualia without propositional content.

Husserl, who wrote a book entitled Cartesian Meditations, was also not describing objects presented to a fixed subject but instead a temporal yet transcendental process or life that could become present to itself. Heidegger subtracts from Husserl the notions of self-presence and direct evidence. Yet Heidegger remains in some suitably changed sense a phenomenologist. He does not admit any direct presence but he still speaks of our getting in touch with a basic temporalizing process, though his language gets very contorted as he tries to avoid speaking in terms of objects presented to a subject.

Can we imagine a way of talking about experience that is neither Cartesian nor Kantian? The difficulty we have imagining this is a measure of the hold Heidegger thinks that the Cartesian paradigm has upon us. For him it should be possible to talk about the revelation of beings without speaking of the direct presence of objects to subjects. His awkward neologisms and his talk of the "revelation" of things

$5 \quad$ In ethics, Heidegger has seemingly little to say. However there are many implications that his thought offers for conduct; they have been pursued by others and become more obvious as his early lecture material becomes available. His explicit social philosophy, what little there is of it, would be antidemocratic and elitist, and he would share conservative doubts about technology and progress. It may be, however, that his ideas could lead in a very different direction than his upbringing and prejudices suggest (see, for example, the work of Reiner Schürmann). 
(and concealment, appearing, open, region, presence, Da-sein, and so on) testify to the difficulty involved.

Much of what Heidegger says stems from a fundamental claim about what it means for something to be. For Heidegger, there is no being that is simply and purely actual in the present moment. "Higher than actuality stands possibility." (SZ §7C) This is possibility lived as possibility, which is not just delayed or alternate actuality.

So he will be opposed to positivist sense data, Platonist intuitions, and isolated intentional acts, since all of these involve purely present and complete entities. Understanding the self or our tools or art works or any other kind of beings will involve understanding their context and the background within which they pursue their careers: in Heidegger's jargon, the world they are revealed within and the way their being is projected against the horizon of time.

This makes Heidegger similar to many contemporary holists, for whom items have meaning because of their places in a system of actions, and propositions are given meaning by their inferential relations in a system of other propositions. But this is not enough for Heidegger. Contrast effects that are in principle a-temporal are not enough. Inference relations are connections within a calculus, and not in themselves temporal relations. For Heidegger, to be present is to be related to absence and possibility experienced as possibility. A holistic system is still a net of related actualities, some of which happen not to be present at the moment.

Heidegger opposes the common view of time as a series of moments, each complete in itself and each fully, if fleetingly, present to a subject that by some synthetic act brings time together in presence and memory.

"From its beginning, whenever it thought about time, philosophy also asked where time belongs. What philosophy primarily had in view was time calculated as a sequence of the succession of consecutive nows. It explained that there could be no numerically measured time with which we calculate without the psyche, without the animus, without the soul, without consciousness, without spirit. There is no time without man. But what does this 'not without' mean? Is man the giver or receiver of time? Is man first of all man, and then after that occasionally...receives time and relates himself to it? True time is the nearness of presencing out of present, past and future--the nearness that unifies time's threefold opening extending. True time ... has already reached man as such so that he can be man only by standing within the threefold extending, perduring the denying and withholding nearness which determines that extending. Time is not the product of man, man is not the product of time. There is no production here. There is only giving in the sense of extending which opens up time-space." (ZS 16)

Time for Heidegger is more than the presencing of that part, then this part, then the next part. It is not the presencing of self-contained definite items that have labels as pasts, presents, and futures. Higher than actuality stands possibility. 
Heidegger refuses to have time be a series or summation of presences. Time is not entities present in past, present, and future. Time is not the presencing of self-contained pasts, presents, and futures. Entities presence out of past, present, and future. ${ }^{6}$

In what way is this any more than the sequential presentation of temporal parts? Time for Heidegger is more than the presencing of this part, then this part. Or even the presencing of this part as this part, with reference to others. This is still not enough, because the parts are each presented complete then summed by the subject. Furthermore, the references of such parts to one another are not temporal in the strong sense Heidegger wants.

Time is not just a peculiar predicate, one more property of an object (or a state of the subject). Time has to do with what allows there to be predicates describing revealed entities at all. By being lived: Heidegger's descriptions are not formal structures but are in terms of giving, withholding, revealing, concealing, extending: a kind of "experience" but not of objects to subjects. A kind of experience, but not in the Cartesian inner theater. What kind of experience?

To speak of possibility as possibility is more than to speak as if there were a set of definite states of which some happen to be past, while others are yet to be manifested as the moving window of the present passes along the series. Nor is it enough to envision a set of states that contains multiple branchings.

Discussing time and possibility in Heidegger, William Blattner points out that a role we might play, such as being-a-lawyer, "is not an end-state" we might aim at, but "is always futural with respect to action." 7 While my belonging or not to the class of lawyers can be ascertained through a small set of criteria, what it means to be a lawyer is not exhausted by any definite set of actions or states. As long as I am committed to the role, being-a-lawyer stands before me as a possibility that remains open to multiple realizations that cannot be specified according to any rule. Yet such futural possibilities are not completely indefinite. Being a lawyer may not be totally specifiable, but there are actions that will not count as fulfilling that role, and it is different from the role of an orchestra conductor or a football player.

This futural dimension of possibility is not a reference to definite items that are not yet present. Futural possibility is not delayed actuality. There is an excess of possibility (though not of already definite possibilities).

This idea can be extended beyond those roles that one chooses to adopt, such as being-a-lawyer.

6 There is "a reaching out that opens up, in which futural approaching brings about what has been, what has been brings about futural approaching, and the reciprocal relation of both brings about the opening up of openness .... The unity of time's three dimensions consists in the interplay of each toward each. This interplay proves to be the true expanding, playing in the very heart of time." (ZS 15)

$7 \quad$ William D. Blattner, “Existential Temporality in Being and Time (Why Heidegger is not a Pragmatist)," in Hubert Dreyfus and Harrison Hall, eds., Heidegger: A Critical Reader (Oxford: Blackwell, 1992), 105. 
What the later Heidegger is most interested in is how we are more globally located and constituted beyond our choice as we find our selves addressed by roles and defining possibilities of talk and action.

There is no such thing as generic humanity; human being is always in some world. One meaning for "what addresses us" is the call of the overall role of our insertion into that world. (Later, we will need to question the unity of these worlds and roles.) Heidegger takes "being a medieval Christian" or "being a modern Western individual" as large scale futural possibilities that address us. They are determinate in that they are different from each other, but they do not specify a set of determinate future states.

We find ourselves already operating within these possibilities. They are in our future, as possibilities that cannot be completely defined in advance. They are in our past, as events of definition or inauguration that we did not and cannot directly experience, because they set us up as the sort of experiencers we are. Yet because they are not specifications for definite realizable states, we have some interpretative latitude. This allows what Heidegger in his early work called "retrieval" (Wiederholen) and later "listening to what addresses us," the attempt to respond in new ways by hearing in that past and future address renewed ways of being in our world.

Heidegger sees language as more than a system of elements and substitutions. Language addresses us prior to our speaking. We are already in language; when we begin to think, an address has already been responded to. We do not face that call or address as distanced spectators, for distanced spectation is a mode of language use.

Where in language is this call? Not in the grammar, for Heidegger thinks that a single natural language, say German or Latin, has been used in responding to more than one of these calls. Since the call is not itself a system of elements, it is not anywhere in the languages as we schematize them, but where the call has its most impact is in the lexicon. When Heidegger discusses the way he thinks what addresses us changes through history, he turns to the introduction of new terms and philosophical words.

Such changes are not merely philosophic events; the philosophic change speaks as a response to an address that influences our whole world, our self-definition and our goals. Heidegger insists that these changes are not wholly at our initiative, though the responses come through us (and, of course, without us there would be no place for such futurity and meaning).

What it means to be human (Dasein) is to find oneself already addressed within a world, to be what Heidegger calls "thrown projects." We do not face neutral data which we then interpret to build a world, and we cannot pull back into some pure subjectivity where we can see our projects from a distance and decree or revise them. Any meaningful action or thought happens within an ongoing project. This includes the action of self-criticism and revision, and so the action which is the doing of philosophy.

A straightforward way to interpret all this would be to equate what Heidegger is talking about with the fact of being socialized. When you become a lawyer, you are socialized into an ongoing social practice which is not specifiable by a set of rules. As conditions change that practice can be changed or extended. Some extensions will be judged to go too far, others to successfully reconfigure what it means to be a lawyer. Blattner's "futural possibilities" include the open but not indefinite potentiality of the 
present practice to be reconfigured. So when Heidegger talks about an "address" to us he would be referring to our being socialized into such practices. When he talks about "retrieving" new possibilities he would mean the extension or change of current practices.

This explanation could be extended from local practices such as being a lawyer to the more global practices such as "being a medieval human." We find ourselves defined within an already going concern that we did not choose to enter. The address or call would be that aspect of our experience and tradition that we inherit, deeply settled beliefs and practices, which we live as our approach to the world, but which we have some power to help reconfigure by various causal processes and/or redistributions of linguistic habits.

In what follows I want to explore ways in which Heidegger might be unhappy with this interpretation, and what other contributions he might make.

It is clear that the "retrieval" Heidegger speaks of is not performed by surveying then revising a current system of discrete elements. Futural possibilities cannot be surveyed. Nor is retrieval a judgment of efficiency applied to a current state of affairs. Nor is it random variation in a set of practices, with variations to be selected for by their success. It is not the exercise of pure self-reflection hovering over any kind of present data or map of a present system. This leaves open, however, an interpretation of futural possibility as being socialized into the kind of practices that Hubert Dreyfus has talked about, where the practices cannot be summed up in any collection of presented data, rules, or the like. ${ }^{8}$

The difficulty I have with that interpretation is that it makes each occasion of retrieval a reference to a different earlier state of the practice in question. According to the interpretation of the call or address as our socialization, the going concern into which we were socialized was formed as a response to an earlier stage of that (or another) practice. But for the later Heidegger, the going concern and its possibilities are a response, yes, but not to an earlier going concern. The earlier activity responded to the very same address that we are now to hear and from which we are now to retrieve new possibilities. The address is not from the present or past state of any thing. It is always "contemporary" yet always past, and this rhetoric has more suggestions of Søren Kierkegaard than of John Dewey. ${ }^{9}$

It is just this, of course, which is rejected as mysticism or mystification by the pragmatic appropriation of Heidegger's ideas. It is also viewed with suspicion by Heidegger's deconstructive descendants. I have my own worries, as well. But I want to pursue the possible contributions that might be found here.

It can sound as if Heidegger were proposing some special experience behind our way of life, a

8 See Hubert L. Dreyfus, Being-in-the-World: A Commentary on Heidegger's Being and Time, Division 1 (Cambridge: MIT Press, 1992).

9 There are complications to be thought here that are introduced by Heidegger's notions about "the history of being." Yet it remains true that the address is not an entity or a state of a system that evolves through time. 
kind of phenomenological Neoplatonism where we leave the world and draw near to a formless source from which all comes. Heidegger is sometimes interpreted that way, and some things he says encourage that interpretation.

The problem is that there would have to "be" some pure address (Zusage) or pure Event (Ereignis) that we could respond to or contemplate on its own. Such an address or event would be a strange superobject presented to us. But Heidegger's goal is not to bring some deeper new foundational entity before our gaze. Heidegger's key claim, over and over, is that the conditions for the appearance of beings are not themselves beings that appear. And this does not mean that they are super-beings, appearing on some expanded ontological map. ${ }^{10}$

Yet Heidegger does seem to be talking about something prior, even if this is not some special entity. Could we perhaps say that he seeks the formal conditions of the possibility of being in a world of action and discourse? What Heidegger is doing is very close to transcendental philosophy. Kant and some of his successors work at describing "from the inside" the necessary conditions that make experience possible. They do not seek an Archimedean point outside of experience. Heidegger's is a related analysis, though based on a different notion of temporality, and with the huge proviso that there can be no purely formal conditions. Forms are beings, too. In a gesture reminiscent of Hegel, Heidegger is taking what he finds as the conditions of the possibility of appearance and applying them to the appearance of those conditions themselves. That this does not lead to a transparent self-understanding or self-coincidence is a gesture ancestral to deconstruction. There is no presence of a form that is not temporalizing, responding to an address offering excess possibility that cannot be summed up or formalized. ${ }^{11}$

These conditions cannot be expressed in a formal way? We might pause a moment to ask whether this would have implications for the status of the standard formal structures, such as mathematics or the logic. Heidegger would say that these too are systems of entities revealed in response to an address; they do not really have the absoluteness and context-independence they appear to have.

But notice that I just used a metaphysical polarity, appearance vs. reality, and I enunciated a position on the nature and status of formal structures. If I am right Heidegger's attempt to go beyond taking ontological positions implies such an ontological position. There is also an epistemological 10 Heidegger speaks of a realm (Bereich) into which we are admitted and whose contours we respond to. He speaks of a gathering (Versammlung) which is performed in the Zusage that addresses us. (Alles Tragen, Zutrag und Entgegentragen, erst und nur der Versammlung entquillt (US 108/WL 19). This Versammlung is not a gathering of actualities in a matrix. Winke und Gebärden sind...verschieden von Zeichen und Chifren, was alles in der Metaphysik beheimatet ist (US 117/WL 26); Winke brauchen den weitesten Schwingungsbereich ... worin die Sterblichen nur langsam hin- und herziehen (US 119/WL 27). This swinging space is not the space of a single system, but neither is it an empty, purely formal openness.

$11 \quad$ Heidegger is still doing something related to transcendental philosophy even as late as Was Heisst Denken, where he links the Event to the grounding of science, and to what science "cannot think." Heidegger's life shows that he kept trying to be the thinker who questioned and legislated from a higher or deeper point of view: even in his latest thought he was still up on the pedestal trying to set agendas. 
position: the claim that self-reflection is not Archimedean. Self-reflection is not pure, cannot achieve a pure view, because there is no such thing as a pure view. Thus there is in the later Heidegger both a challenge to the standard way of doing philosophy by mapping and constructing positions, and some taking of positions, for instance one challenging a widely held presupposition about the status of formal systems.

Now, if there is no purely formal address to us, then there is no shapeless space within which action or thought can move at whim. This means, for Heidegger, that there is some guide (though no rule) for retrieving, rereading and renewing our texts and traditions. This conservative side of Heidegger is often under attack today: his talk about the address to us provides essential possibilities, a true home, some weight to us (and so is anathema to deconstruction), but it is not to be equated with the present state of some social or intellectual system (and so is rejected by pragmatists). I am trying to probe for ways in which this address might offer a contribution that should be distinguished both from traditional essentialism and from the deconstructive and pragmatic attacks upon essentialism.

For Heidegger there is something to the West, to the Greeks, and to us moderns, something beyond practices and beyond metaphysics, yet not dissolved into the play of the signifier. There is something we can retrieve which is more than generalities about différance or the formal conditions of possibility for any identity (though often enough that is all Heidegger gives us). What we can retrieve, however, is not a fixed identity we can seize upon. Higher than actuality stands the excess of possibility. The address cannot be actualized, fixed, or represented. Nor is it a generality that simply gathers a set of particular actualizations. It remains open to a retrieval that can change us in ways we cannot know or expect.

The address never gives us the presence and completeness that it seems to offer. As futural possibility it can never close on itself in the achieved actuality it invites us toward. There is no solid essential identity. Talking about this aspect of Heidegger, Derrida says of the address to us (which he calls la promesse, translating Heidegger's Versprechen) Elle ne peut pas ne pas s'y manquer. ${ }^{12}$ The promise exists only by necessarily falling short of itself.

But there is in the address a still deeper departure from traditional ideas of essence and definition: what opens space for us must also mislead us.

We touch here on Heidegger's ideas about the finitude of any address or revelation of beings, and the necessary "error" (Irre) into which we are carried..$^{13}$ This is related to Kant's idea that reason is carried 12 Derrida, De l'Esprit, 146.

13 "Nearing nearness has the character of denial and withholding .... The giving that gives time is determined by denying and withholding nearness .... We call the giving which gives true time an extending which opens and conceals." (ZS 15f). Cf. Vom Wesen der Wahrheit (in Wegmarken [Frankfurt am Main: Klostermann, 1967]; the English version by John Sallis is found in Martin Heidegger: Basic Writings, edited by David Krell, [New York: Harper and Row, 1977]). 
by its own momentum into realms of illusion. For Heidegger this finds several causes. The first is that the conditions for the appearance of beings are not beings that appear. What appropriates us into a world, the address that is time opening possibilities, is in a sense invisible even though and because it is everywhere. Since the address is not a foundational entity, it has nothing to say for itself. Though we respond constantly to the address, we do not hear it as an object in our world. So we are tempted to understand ourselves and the world totally in terms of the relations between the entities revealed. This misapprehension is not our fault; it is a structural inevitability. It is to some degree correctable by attempts such as Heidegger's. But since the address is not an entity nor a form we can focus on, we can never achieve a complete self-comprehension that avoids falling back into error about our way of being and listening.

I said earlier that Heidegger's discussions of listening sound more like Kierkegaard than Dewey, because the address cannot be identified with the present state of any system or situation. Here is another way: our self-appropriation constantly goes astray; authentic listening and retrieval cannot move into a clear zone of achieved self-completion. Yet some listening and retrieval can still be more "authentic" than others.

The address we listen to and retrieve from is not a philosophical system or position. But positions are not far away. Heidegger interprets historical philosophical positions as themselves responses to what addresses us. He does not think that philosophers just invent optional "world-views." At times Heidegger goes too far, as when speaks of Leibniz's monadology or Aristotle's physics as themselves having the necessity and inevitability he attributes to the address itself (see EPH /375). At other times he speaks as if what Aristotle or Leibniz wrote was a response to what addressed them. The latter position seems to me the only consistent one. ${ }^{14}$

If Aristotle and Leibniz were responding to what addressed them when they developed their systems and novel philosophical positions, then our listening and retrieval cam also lead to new systems or new positions. This would be a way of generating positions on the philosophical map, but it would respond less to the currently existing battle of opinions and more to possibilities retrieved from what addresses us (perhaps in earlier texts, or through poems and texts and events outside of philosophy). Such a position might make a place in current debates yet be responding to more than the existing maps. It would be more like raising Atlantis from the sea bed than staking out a new fort on familiar terrain.

However, Heidegger's own retrieval interpretations (for instance his readings of Plato, or of the Presocratics, or of Hölderlin) do not generate such new systems or positions. Heidegger retrieves from many texts indications of what he considers a "more original" task of thinking. It would be a more "authentic" listening to find a step back from our practical and metaphysical debates to a dwelling with that address or event that makes them possible. Heidegger claims that the most authentic retrieval would include thinking about listening itself, and about retrieval, and about their inevitably finite and misleading character. However, since that address or event is not a thing or form that can be grasped and dwelt with, authentic listening would constantly fall away from its openness and slip into standard 
positions on ordinary maps.

Because of this concern for authenticity as a step back to acknowledging our receptive situation, the interpretations Heidegger offers resemble one another. The "bad guys" all look like Plato or Descartes, while the "good guys" all look like secret Heideggerians. But with closer reading one sees that while the same step back is being listened for in many texts, the modes and directions vary, as do the ways in which the retrieved possibilities relate to time and nature. In addition, it becomes apparent that there are no pure bad guys and good guys, but that even the most metaphysical of texts harbors traces of the other task of thinking. Heidegger certainly does want to find everywhere traces of the original premetaphysical call to the Greeks. But this is not only his intellectual imperialism. Part of what he is claiming is that our thinking is still responding to that call and always exposed to the possibility of a different relation to what has addressed us. He wants "to say something to the present which was already said a long time ago precisely at the beginning of philosophy and for that beginning, but has not been explicitly thought." (EPH 379) $)^{15}$

There is another way we can be misled by what addresses us. In his earlier writings Heidegger insisted that there were multiple aspects or dimensions in the event of our being-in-the-world that do not unfold from a single source. These dimensions are not derived from some overarching first principle; they are not related in a dialectical whole, nor arranged in a hierarchical unity (they are "equiprimordial"). In his later writings Heidegger finds in the opening of futural possibility "regions" that do not sit smoothly together, yet must "extend" together for there to be a "there" here. So he speaks of the tear (Riss), and the Heraclitean strife (polemos), and he speaks of the tension between revelation and concealment, the conflict between earth and world, and so on.

I said earlier that futural possibilities are not a system of determinate elements. Now I must add that the region opened by what addresses us is not a peaceable kingdom. The point here is not diversity, it is conflict. This is obviously one of those places in Heidegger where he has to work hard not to become Hegel, but he insists there is no system, no whole, no balance, only an interplay of dimensions and no closure of possibility.

I think Heidegger should go further with this tension. Despite what I have said above, his talk about authentic dwelling with what addresses us too often slides into an easy essentialism, as in his discussions of modern technology. While he is careful to make the event of our being addressed fraught with tensions and incompletions, he is too quick to summarize what is delivered in the address to the various epochs in his history of being. That is, in his ideas there is more of a form/ content division than

15 Heidegger does not speak as if this listening will, of itself, allow a new beginning separate from our heritage. If that is to happen it will not be through our initiative or retrieval, though listening will be involved. There is ambiguity in Heidegger about whether a new beginning will be achieved through a retrieval of more original possibilities from our heritage, or whether there would be an entirely new address to us. I suspect that this issue, like issues concerning just how our Western heritage is related to, for instance, the East Asian heritage, remains undecided for Heidegger. (On this, however, see my The Critique of Pure Modernity: Hegel, Heidegger, and After, 230-236.) 
he wants there to be. And if that division is inevitable, as I think it is, then perhaps there would be room for an even less essentialist conception of the address, which would take the idea of excess possibility further than he has done. So I agree with the deconstructive criticism that Heidegger is too much in thrall to the idea of unified epochs. But even if we say that what addresses us is more multiple than Heidegger allows, the address or call does not collapse into the pure play of the signifier. Nor, as I have argued, does it become the pragmatic reinterpretation or extension of a currently definite system.

If there is anything to Heidegger's idea that what addresses us misleads us and opens a space which is by no means harmonious (and I am suggesting that there is even more to it than Heidegger says), then we should be alert to for the self-subversion of positions on the philosophical map. A position's stability is remains addressed by excess possibility. There may be fifth columns within the forts. (We could also note in passing that this suggests yet one more caution against easy intuition mongering.)

Finally, what Heidegger says about our being led and misled shows that what he means by our being addressed is not our being socialized into a Wittgensteinian practice or form of life. The tensions Heidegger speaks of cannot be cured by bringing language home, for these are domestic tensions. Hence, again, what I have been saying somewhat differs from Hubert Dreyfus's more Wittgensteinian interpretation in terms of basic practices. That reading makes it difficult to understand why Heidegger would claim that what addresses us also misleads, since it suggests that whatever tensions exist are due to our own misprision.

There is a further practical implication to what I have been saying. Heidegger is offering a revised notion of critique. Rather than seeing the task of the thinker to be attack and victory, Heidegger speaks of critique as letting something be in its place. In so doing, the thing's limits and dependencies appear. Critique consists of listening to the text and finding out its limits rather than taking it on as an adversary. This kind of critique is not out to capture an enemy fort; it does not eliminate what it critiques. For example, Heidegger says that the metaphysics he constantly critiques is "unavoidable" (unumgänglich (US 116/WL 25)); we can't just "leap out of the circle of representations that has ruled us so far" (US 130/WL 36). But we can hear it as a response to something more excessive.

Through his notion of listening to what addresses us, Heidegger is in effect aiming this kind of critique against the entire position-taking-and-attacking activity of traditional philosophy. He tries to show that there is within philosophy a thinking that conditions its activity but does not operate according to its rules.

If there is an address to which we respond, and we have no role that is not such a response, then even the seemingly neutral and self-reflexive, self-correcting role of philosophy itself has hidden substantive content. For Heidegger that content comes to the fore in our time: the will to power. Power is the unspoken component and goal of all attempts to win on the field of battle, but also of attempts to lay all out before us in peaceful harmonized systems. Given Heidegger's aversion to the technological world, and his nostalgia for an idealized peasant life, it is easy to dismiss his comments on power and technology by pointing out the importance for survival of our coming to understand and manipulate 
nature. But this would be too easy. Heidegger is claiming that there is a basic dimension to our own existence that cannot be described in terms of power and its objects. Listening, in his sense, cannot be forced and is not a conquest or a manipulation. Power-philosophy misses that dimension of our being.

His version of critique may appear to be a kinder, gentler way of doing philosophy. It suggests a mode of dialogue that lets the other be. But it has its own violence, for it refuses to accept the other's selfconception. Furthermore, it is often practiced badly. Many of the practitioners of this style of criticism within continental philosophy are guilty of the worst superficial vest-pocket dismissals of what they claim to be letting be. Heidegger often sins in this regard in his quick remarks about other thinkers, but less often when he engages at length with a thinker's text. One can disagree, and I do, with his lengthy treatments of Hegel, or Plato, but they offer thoughtful models of criticism. They do not maneuver around positions on a field of argument and refutation. They try to let the other be and reveal the limits (and the self-transgression) of the space in which it stands.

This sort of critique is not new, but it has been usually mounted from a superior totalizing position (Hegelian or Marxist knowledge of the whole, or some semantic or social scientific metaposition). Heidegger (and, I think, Wittgenstein) tries to make this kind of critical gesture without claiming to be talking from a superior mapping position above it all. ${ }^{16}$

I have tried to spell out some implications of Heidegger's ideas for the standard position-anddebate style of philosophy. I also indicated several standard-style positions that seem to be implied in Heidegger's talk about the task of thinking.

We might ask: how firmly Heidegger is committed to the positions and implications I mentioned? I spoke earlier about appeals to "experience." For Heidegger, I think, the experience of the address is primary. With all due cautions expressed, that is his equivalent of Husserl's transcendental life coming to find itself.

There is no set of propositions whose acceptance is necessary for that listening, although there are some sets of propositions whose acceptance may block it. The positions I mentioned are surely involved in what Heidegger is saying, and there are others as well concerning time and the nature of language. But were the positions shown to be inadequate, Heidegger would not give up the experience. He would deny that his task for thought rests on these positions. That is a sense in which he is still a phenomenologist. But a non-Cartesian one, for there is no need to get a firm foundation.

Heidegger wants us to experience the receptivity underneath our active debating thought. He did

16 In many ways what Heidegger says about philosophy as an activity goes Aristotle one better. Aristotle said that philosophy was an activity of leisured men that satisfied a need to live well that could only be fulfilled when ordinary wants were satisfied. Ordinary laborers (mekhanikoi) could not reach the kind of "useless" thought that contemplated those necessary truths that structured the grounds and goals of the labor they performed. For Heidegger the contemplative truth-discover, philosophy, is itself a kind of laborer in the service of a demand whose provenance it is unaware of the need to inquire about. But Heidegger's still more "useless" thought can so inquire. 
not particularly want this to lead to the generation of positions on the philosophical map, but it may do just that, either through retrieve or through what is needed to explicate his own ideas. Still, we should remind ourselves that our positions in debate are not the same as our locations in the world.

David Kolb

Bates College 